\title{
ANALISIS DAN RANCANGAN SISTEM E-VOTING PEMILIHAN KETUA OSIS
}

\author{
Yusri ikhwani \\ Fakultas Teknologi Informasi, UNISKA \\ email : yusri.ikhwani@gmail.com
}

\begin{abstract}
ABSTRAK
Dalam memasuki era modern dan pesatnya perkembangan teknologi saat ini, manusia mengenal teknologi yang semakin maju dan terjangkau untuk mempermudah melakukan berbagai kegiatan dalam kehidupan. Kemajuan teknologi sangat pesat terjadi dalam berbagai bidang, contohnya di bidang transportasi, komunikasi, kesehatan, pendidikan, dan bidang lainnya sehingga membuat manusia semakin memerlukan teknologi untuk mempermudah segala pekerjaan dalam kehidupan ini. Pelaksanaan Pemilihan Ketua OSIS dengan menggunakan sistem pemilu ini merupakan sebuah proses pembelajaran demokrasi secara langsung bagi seluruh siswa. Dalam melakukan kegiatannya pemilihan ketua OSIS pada sekolah masih sering ditemukan menggunakan media penyampaian informasi yang sederhana yaitu berupa hanya lembaran kertas untuk penyampaian visi dan misi, kemudian ketika pemilihan pun masih menggunakan lembar kertas untuk memilih calon sehingga masih belum maksimal. Dengan memanfaatkan teknologi komputerisasi dengan menggunakan aplikasi pemilihan ketua OSIS (e-voting) berbasiskan web bisa membuat kegiatan pemilihan ketua OSIS lebih mudah dalam penyampaian informasi, lebih cepat dalam melakukan perhitungan suara, serta membuat lebih hemat terhadap kertas sehingga hasil yang didapat bisa efektif dan efisien. Sehingga perlu melakukan penelitian untuk menganalisis, merancang dan implementasi Sistem EVoting Pemilihan Ketua OSIS dengan berbasis Web Pada Sekolah.
\end{abstract}

\section{Kata Kunci : Borland Delphi, Pengelolaan Barang dan Piutang dan Client Server}

\section{PENDAHULUAN}

Dalam memasuki era modern dan pesatnya perkembangan teknologi saat ini, manusia mengenal teknologi yang semakin maju dan terjangkau untuk mempermudah melakukan berbagai kegiatan dalam kehidupan. Kemajuan teknologi sangat pesat terjadi dalam berbagai bidang, contohnya di bidang transportasi, komunikasi, kesehatan, pendidikan, dan bidang lainnya sehingga membuat manusia semakin memerlukan teknologi untuk mempermudah segala pekerjaan dalam kehidupan ini. Saat ini dunia telah mengenal suatu teknologi yang disebut dengan komputerisasi. Dengan komputerisasi semua orang dapat mengelola data dan berkomunikasi dengan mudah. Melalui komputerisasi, setiap orang dapat memperoleh dan menyampaikan berbagai informasi yang dibutuhkan kapan saja dan dimana saja. Kini dengan komputerisasi manusia dapat terbantukan dengan baik dalam melakukan kegiatan seperti halnya pemilihan dengan menggunakan e-voting.

Pembelajaran demokrasi kepada siswa sederajat SMA/SMK sangat penting karena siswa adalah pemilih pemula bagi pemilu legislatif dan presiden yang dilaksanakan setiap 5 tahunnya. Kegiatan yang mengadopsi sistem pemilihan yang dilaksanakan oleh KPU ini di dahului oleh penyampaian Visi dan Misi calon ketua OSIS dihadapan seluruh siswa. Prosedur pemilihan ketua OSIS merupakan agenda tetap bagi pengurus OSIS. Setiap siswa bergantian memberikan hak suaranya di mulai dari siswa kelas X sampai dengan kelas XII.

Pelaksanaan Pemilihan Ketua OSIS dengan menerapkan sistem pemilihan umum (pemilu) merupakan sebuah proses pembelajaran demokrasi secara langsung bagi seluruh siswa. Diharapkan kedepannya para 
siswa tidak canggung pada saat menghadapi pemilihan umum seperti pemilihan kepala daerah ataupun pemilihan kepala negara, karena sudah memiliki pengalaman pada saat di sekolah. Dan kegiatan ini juga bertujuan untuk menanamkan sikap sportif dan jujur untuk seluruh siswa.

Dalam melakukan kegiatannya pemilihan ketua OSIS pada sekolah masih sering ditemukan menggunakan media penyampaian informasi yang sederhana yaitu berupa hanya lembaran kertas untuk penyampaian visi dan misi, kemudian ketika pemilihan pun masih menggunakan lembar kertas untuk memilih calon sehingga masih belum maksimal.

Dengan memanfaatkan teknologi komputerisasi dengan menggunakan aplikasi pemilihan ketua OSIS (e-voting) berbasiskan web bisa membuat kegiatan pemilihan ketua OSIS lebih mudah dalam penyampaian informasi, lebih cepat dalam melakukan perhitungan suara, serta membuat lebih hemat terhadap kertas sehingga hasil yang didapat bisa efektif dan efisien.

Hal ini sangatlah penting karena dengan adanya sebuah aplikasi ini maka tidak ada lagi kekurangan informasi, buang-buang kertas dan dapat menghitung hasil perolehan suara dengan cepat dalam pemilihan ketua OSIS dan akan mempermudah siswanya maupun guru yang mengawasi pemilihan ketua OSIS tersebut. Dalam penelitian ini akan dibuat suatu aplikasi pemilihan ketua OSIS berbasis web dengan melakukan analisis di beberapa sekolah sebagai sampel kemudian selanjunya merancang dan mengimplementasikan sistem yang dibuat menggunakan software pendukung Macromedia Dreamweaver CS6 sebagai editor, bahasa pemograman PHP dan menggunakan Database MySql.

\section{RUMUSAN MASALAH}

Berdasarkan latar belakang yang sudah diuraikan di atas, perumusan masalah dalam penulisan ini ialah bagaimana menganalisis, merancang dan implementasi Sistem E-Voting Pemilihan Ketua OSIS.

\section{TUJUAN PENELITIAN}

Adapun tujuan yang hendak dicapai dalam penulisan serta pelaksanaan ini ialah agar dapat menganalisa, merancang serta menghasilkan implementasi sistem E-Voting Pemilihan Ketua OSIS berbasis Web pada sekolah.

\section{TARGET LUARAN DAN MANFAAT PENELITIAN}

Target luaran dalam pembuatan penelitian ini adalah diharapkan dapat memberikan kontribusi kepada sekolah untuk memfasilitasi dan dapat digunakan untuk memudahkan dalam proses pemilihan ketua OSIS serta memberikan pembelajaran sejak dini kepada para siswa untuk mengenal demokrasi karena siswa merupakan pemilih pemula bagi pemilu legislatif dan presiden.

\section{METODE PENELITIAN}

Metode penelitian yang dilakukan untuk analisis, merancang dan mengimplementasikan sistem adalah dengan menggunakan metode waterfall, melalui tahapan penelitian seperti gambar berikut:

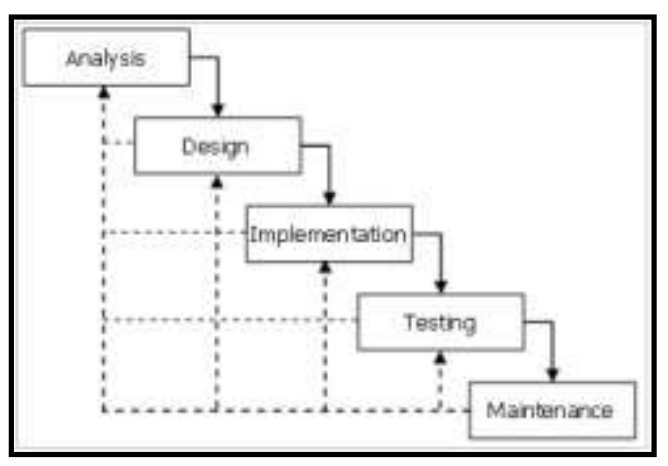

Gambar 2.1. Metode Waterfall

\section{Analisis Sistem}

Analisis sistem merupakan tahapan penelitian terhadap sistem berjalan (analisis sistem berjalan) yang dilakukan sebelum dibuatnya sebuah proses perancangan sistem dengan bertujuan untuk mengetahui permasalahan yang terjadi. Kebanyakan sekolah dalam pemilihan ketua OSIS masih bersifat manual 
seperti siswa yang bersifat menjadi panitia pelaksana pemilihan ketua OSIS tersebut masih menggunakan kertas calon yang dipilih dan panitia pelaksana juga membagi kertas tersebut ke setiap kelas yang melakukan pemilihan ketua OSIS, perhitungan hasil suara yang masih manual maka akan banyak memakan waktu dalam pemilihan ketua OSIS tersebut dan masih banyak terjadi kecurangan dalam perhitungan hasil suara dalam pemilihan ketua OSIS dan juga sulitnya dalam pengawasan pemilihan ketua OSIS tersebut karena pengawas atau pembimbing yang masih mengikuti ke setiap kelas dalam pembagian surat suara atau kertas suara dalam pemilihan ketua OSIS tersebut, dengan adanya sistem e-voting diharapkan dapat meningkatkan kualitas terhadap kemudahan siswanya dalam pemilihan ketua OSIS dengan menggunakan bidang komputerisasi atau sebuah aplikasi yang mana siswa akan lebih mudah dan praktis dalam peleksanaan pemilihan ketua OSIS.

Selain siswa yang bersifat sebagai pemilih, siswa yang bersifat sebagai panitia pun dapat meringankan tugasnya sebagai panitia dalam pemilihan ketua OSIS dan dapat mempermudah pengawasan pemilihan atau dewan guru yang terlibat dalam pemilihan ketua OSIS yang mana sebagai pembimbing atau pengawas dalam pemilihan ketua OSIS, cepatnya dalam penghitungan hasil suara pemilihan yang tidak manual lagi dan tidak ada lagi terjadinya kecurangan dalam pemilihan ketua OSIS atau hilangnya hasil suara dalam pemilihan. dapat mempermudah pengawasan pemilihan atau dewan guru yang terlibat dalam pemilihan ketua OSIS yang mana sebagai pembimbing atau pengawas dalam pemilihan ketua OSIS, cepatnya dalam penghitungan hasil suara pemilihan yang tidak manual lagi dan tidak ada lagi terjadinya kecurangan dalam pemilihan ketua OSIS atau hilangnya hasil suara dalam pemilihan.

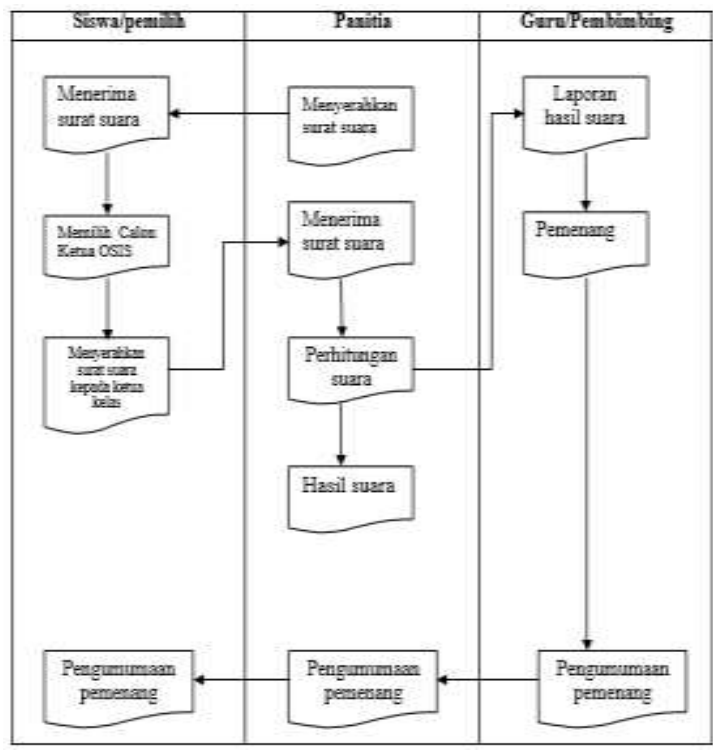

Gambar 2.2. Diagram FlowMap Analisis

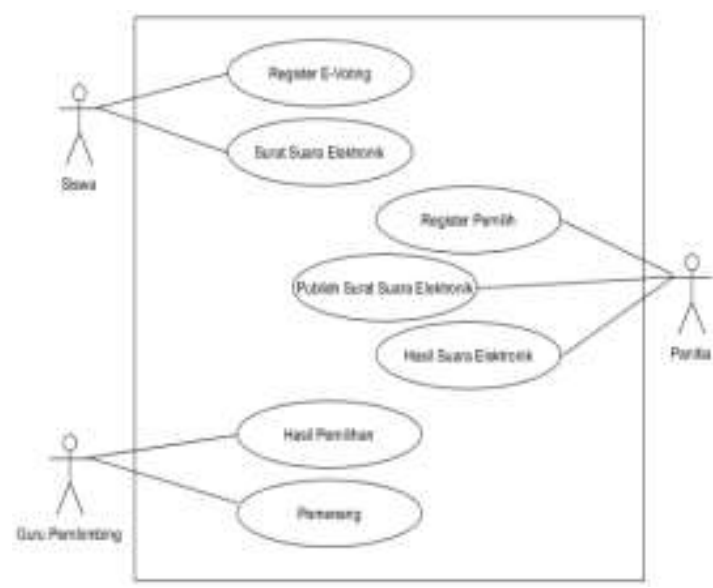

Gambar 2.3. Use case Sistem E-Voting Ketua OSIS

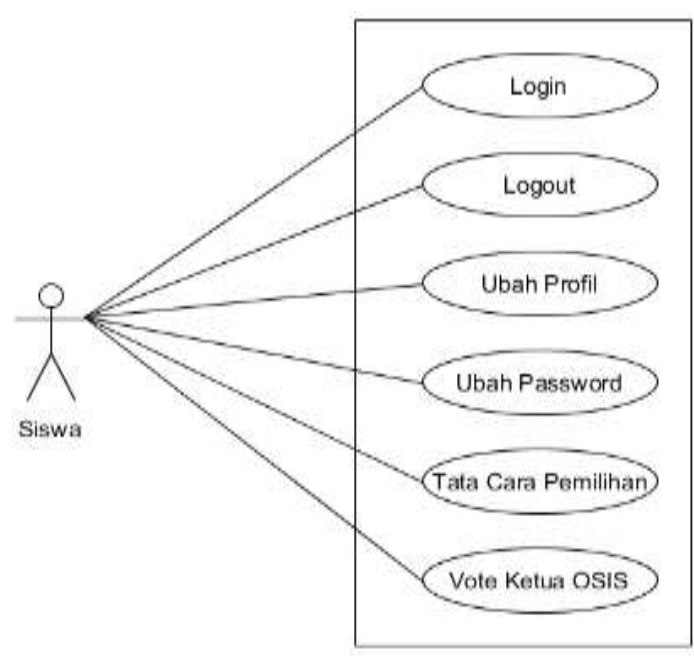

Gambar 2.4. Use Case Siswa 


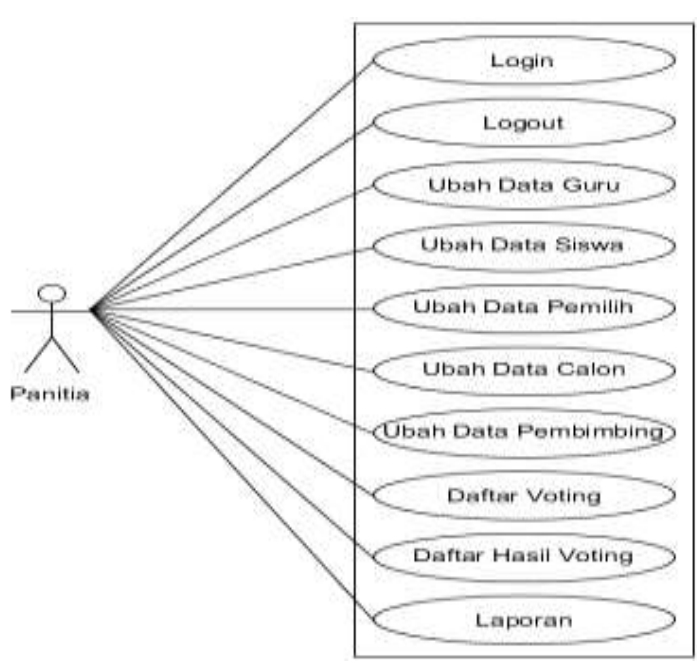

Gambar 2.5. Use case Panitia

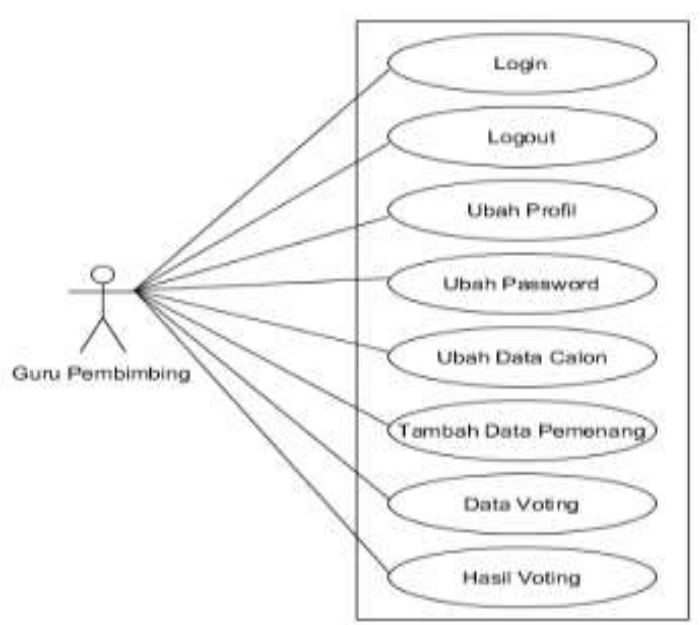

Gambar 2.6. Use case Guru Pembimbing

\section{HASIL DAN PEMBAHASAN}

Tahap implementasi merupakan tahap pembuatan sistem informasi sesuai hasil pada tahap perancangan. Pengimplementasian sistem E-Voting pemilihan ketua OSIS menggunakan PHP/WEB Browser yang mana dapat digunakan di laboratorium komputer sekolah, melalui komputer pribadi siswa maupun smart phone siswa tersebut. Dalam tampilan sistem ini dirancang semudah mungkin dalam hal penggunaan dan semenarik mungkin. a. Form Login

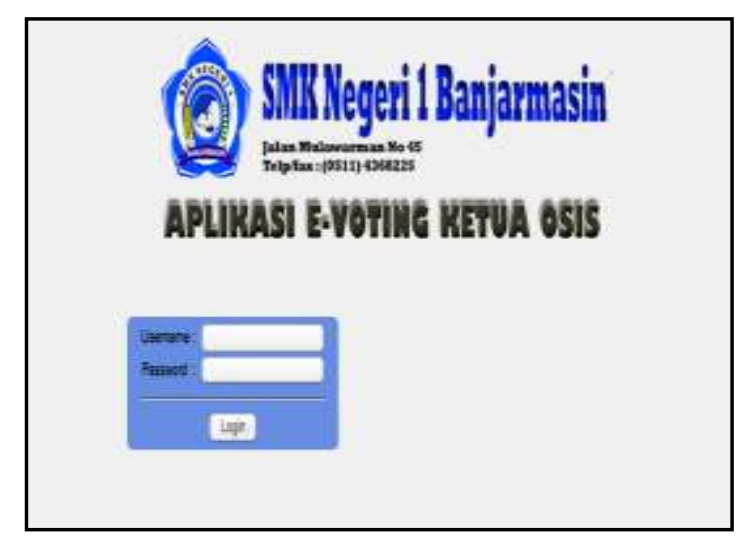

Gambar 3.1. Tampil Login

\section{b. Form Menu Utama}

Menu utama akan terbuka setelah pengguna komputer melakukan login, menu - menu yang tersedia akan di sesuaikan dengan status pengguna komputer. Dibawah ini merupakan interface menu utama :

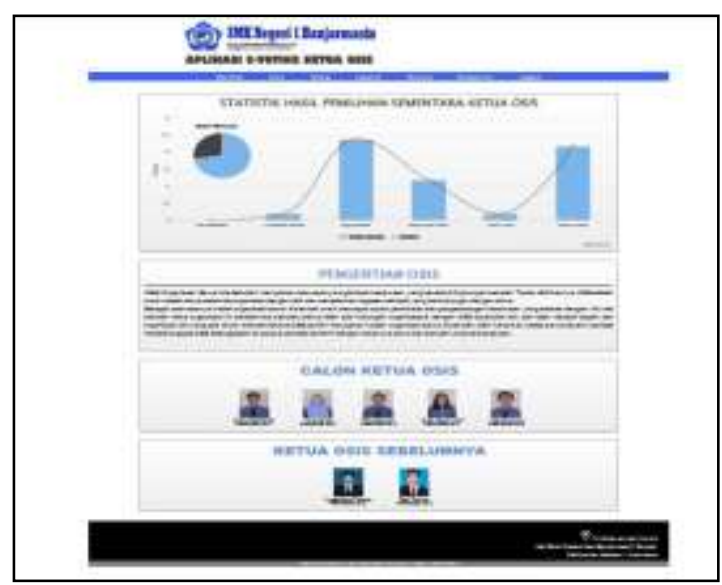

Gambar 3.2. Halaman Utama Admin / Panitia

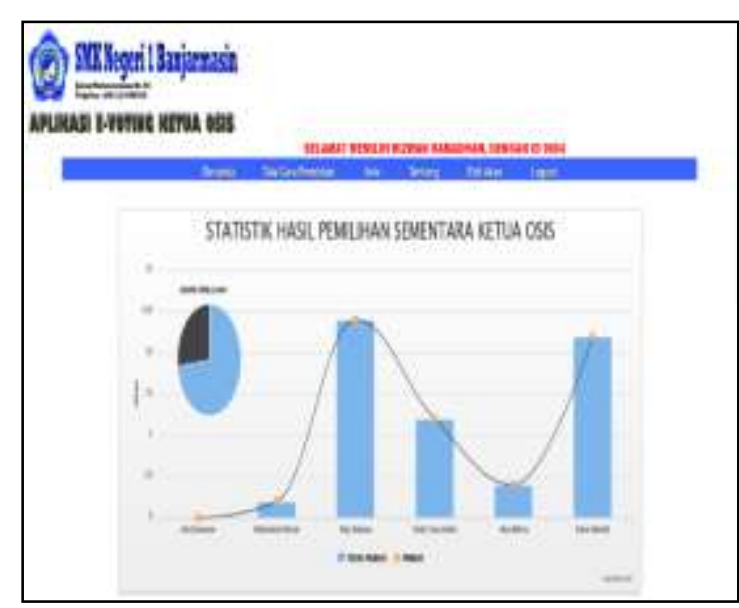

Gambar 3.3. Halaman Utama Siswa 
Form vote digunakan untuk memilih calon ketua OSIS yang mana akan di pilih oleh pemilih/siswa.

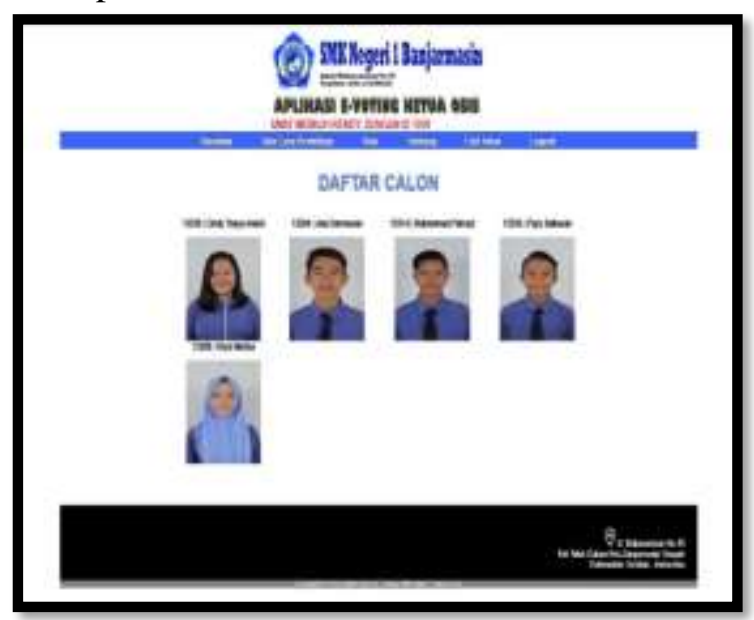

Gambar 3.4. Tampilan Vote diakun siswa

Setelah pemilih mengklik foto calon ketua OSIS maka akan muncul tampilan detail data calon, setelah muncul pemilih melanjutkan dengan mengklik tombol vote untuk memilih calon ketua OSIS tersebut.

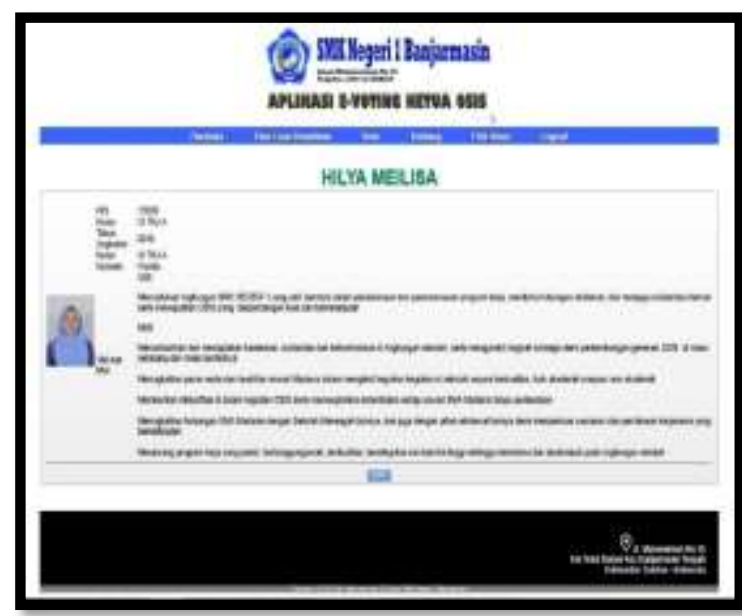

Gambar 3.5. Tampilan Detail Data Calon

Selesai melakukan pemilihan calon ketua OSIS maka akan muncul validasi pemilih sudah memilih calon ketua OSIS.

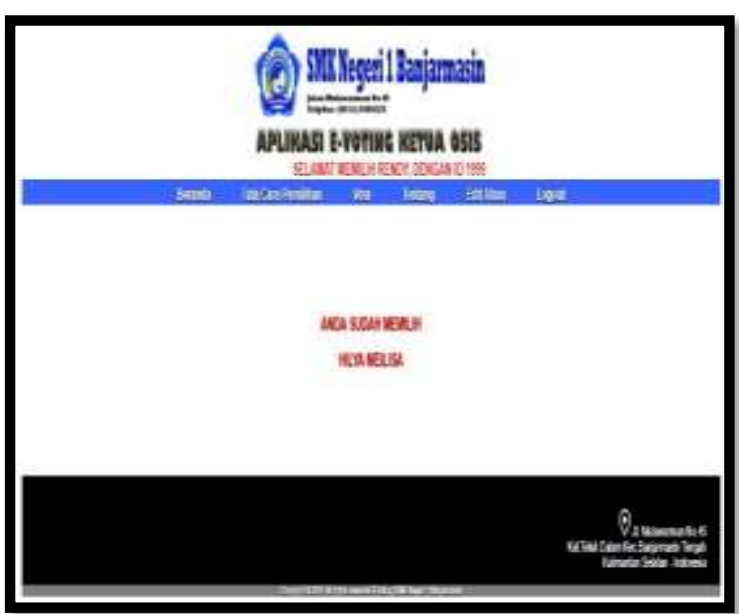

Gambar 3.6. Tampilan Validasi Pemilih

Tampilan Hasil/jumlah Voting Tabel

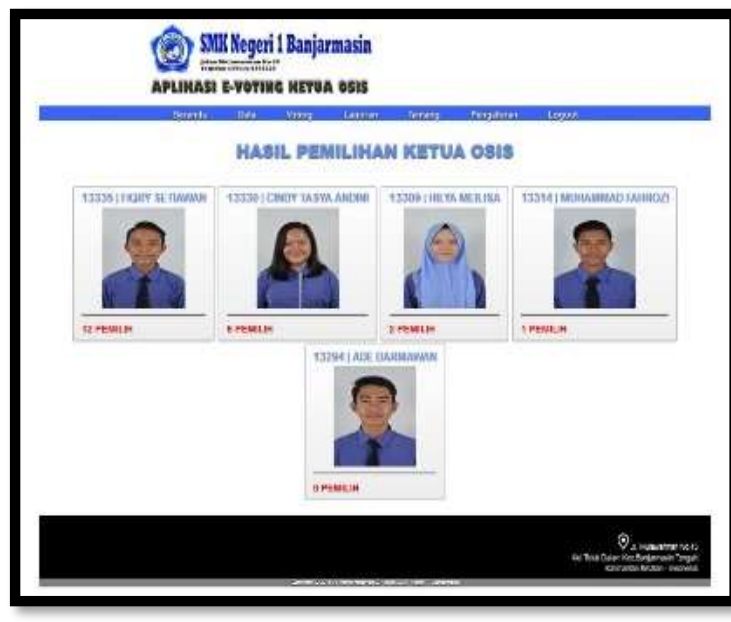

Gambar 3.7. Tampilan Hasil/jumlah Voting Tabel

Tampilan Hasil/jumlah Voting Grafik

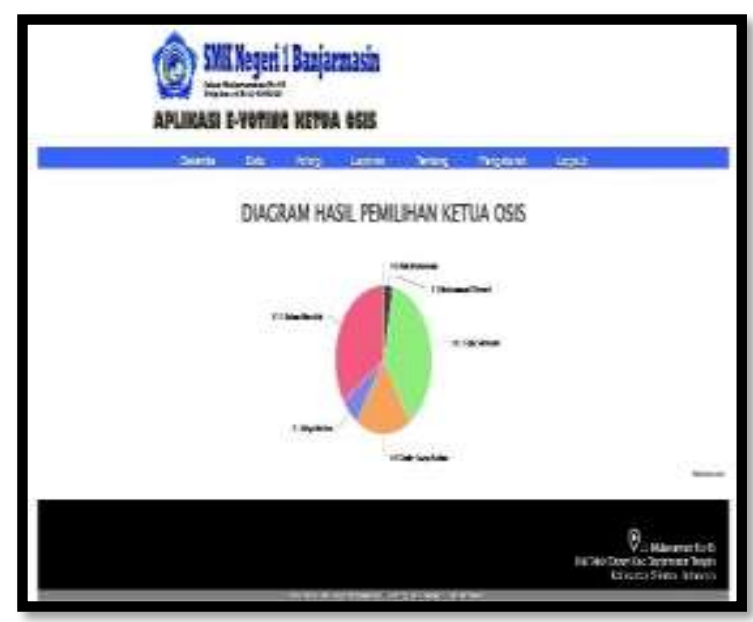

Gambar 3.8. Tampilan Hasil/jumlah Voting Tabel 


\section{KESIMPULAN}

Setelah melalui beberapa tahapan penelitian untuk membuat sebuah Aplikasi E-voting Ketua OSIS dengan melakukan identifikasi masalah, analisis, perancangan, pengujian dan pemeliharaan sistem, sehingga sistem yang dibangun sudah mampu mempermudah proses pengolahan data untuk mendukung pemilihan ketua OSIS. Dari penjelasan diatas dapat ditarik kesimpulan, yaitu :

Dengan adanya Aplikasi E-voting Ketua OSIS berbasis Web tersebut, diharapkan tidak ada lagi kecurangan dalam proses pemilihan ketua OSIS dan akan mempermudah siswanya maupun guru yang mengawasi pemilihan ketua OSIS tersebut. Aplikasi ini membantu pihak sekolah untuk memudahkan pemilihan ketua OSIS serta proses pemilihan ketua OSIS lebih terorganisir dengan baik dari sebelumnya yang belum ada sama sekali atau masih melakukan pemilihan ketua OSIS secara manual.

\section{REFERENSI}

Arbie. (2004). Manajemen Database dengan MySql. Program Pascasarjana Yogyakarta: Andi.

Buyens, J. (2001). Web Database Development. Jakarta: Elex Media Komputindo

HM, J, 2005, Analisis \& Desain Sistem Informasi . Jakarta: Eirlangga Publisher. id, S. (2017, Januari). Pemilihan Calon Ketua

Osis. $\quad$ Retrieved from

www.sman5bdg.sch.id:

http://sman5bdg.sch.id/berita/page/18

5/pemilihan-calon-ketua-osis

Nasional.Kompas. (2017, Januari). Perlukah penerapan.e-voting pada pemilu di indonesia.. Retrieved from Nasional Kompas: akses tgl 20 juli 2017, pukul: 21.01 WITA

Parno, S.Kom., MMSI., (2010), Langkahlangkah Dalam Pembuatan Data Flow Diagram, Surabaya.

Sutarman. (2003). Membangun Aplikasi Web dengan PHP dan MySql. Yogyakarta: Graha Ilmu.

Solichin, A. (2009). Pemrograman Web dengan PHP dan MySQL. Jakarta: Universitas Budi Luhur.

Supardi, Y. I. (2007). Perancangan Sistem dan Basis Data. Yogyakarta: Andi Ofset.

Wahyudi, B. (2010). Perancangan Sistem. Bandung: Informatika. 